\title{
REVITALISASI SEKOLAH BERBASIS BUDAYA MUTU
}

\author{
Hendro Widodo \\ Universitas Ahmad Dahlan Yogyakarta \\ Jln. Kapas No.9, Semaki, Umbulharjo, Kota Yogyakarta, Daerah Istimewa Yogyakarta 55166 \\ Email: hwmpaiuad@gmail.com
}

DOI: $10.29313 /$ tjpi.v7i2.4139

Accepted: October 23th, 2018. Approved: April 9th, 2019. Published: April 9th, 2019

\begin{abstract}
In the context of education, quality includes inputs, processes, and outputs. The three elements are interconnected. That is, to produce a quality educational output, influenced by the process of education, and quality education process will be able to produce better output if supported by the input of quality education as well. Schools can be said to be of quality if the inputs, processes, and output of education can meet the requirements demanded by users of education services, both internal and external. In this case, school quality management is the ability of schools to utilize educational resources both buman and non-human resources to improve the ability of inputs, processes, and outputs of education to meet the requirements demanded by users of education services (stakeholders).
\end{abstract}

Keywords: Revitalization, Schooling, Quality Culture.

\section{ABSTRAK}

Dalam konteks pendidikan, mutu mencakup input, proses, dan output. Ketiga unsur tersebut saling berbubungan. Artinya, untuk menghasilkan output pendidikan yang bermutu, dipengarubi oleh proses pendidikannya, dan proses pendidikan yang bermutu akan dapat menghasilkan output yang lebih bermutu bilamana didukung oleh input pendidikan yang bermutu pula. Sekolah dapat dikatakan bermutu jika input, proses dan output pendidikannya dapat memenuhi persyaratan yang dituntut oleh pengguna jasa pendidikan, baik internal maupun eksternal. Dalam hal ini, manajemen mutu sekolah merupakan kemampuan sekolah dalam mendayagunakan sumber daya pendidikan baik sumber daya manusia maupun non manusia untuk meningkatkan kemampuan input, proses dan output pendidikan guna memenubi persyaratan yang dituntut oleh pengguna jasa pendidikan (stakeholders).

Kata Kunci: Revitalisasi, Sekolah, Budaya Mutu. 


\section{PENDAHULUAN}

Peningkatan mutu sekolah merupakan fondasi untuk terciptanya pendidikan yang berkualitas. Mutu sekolah merupakan salah satu isu sentral dalam pendidikan nasional selain isu-isu lainnya seperti pemerataan, relevansi, dan efisiensi manajemen sekolah. Dewasa ini upaya peningkatan mutu sekolah terus dilakukan oleh berbagai pihak baik oleh pihak yayasan sekolah maupun pemerintah sendiri. Upayaupaya tersebut dilandasi suatu kesadaran betapa pentingnya peranan pendidikan dalam pengembangan sumber daya manusia dan pengembangan watak bangsa (Nation Character Building) untuk kemajuan masyarakat dan bangsa. Harkat dan martabat suatu bangsa sangat ditentukan oleh mutu pendidikannya.

Sekarang ini pendidikan berada dibawah tekanan hebat untuk melakukan perubahan. Program restrukturisasi diterapkan untuk memperbaiki kinerja guru, pengayaan kurikulum, memenuhi permintaan bisa menampung lebih banyak siswa, dan memperbaiki koneksi sekolah. Upaya-upaya perubahan dalam pendidikan itu hanya melahirkan sedikit keberhasilan karena mereka hanya memiliki pandangan sempit tentang pendidikan. Mutu, pada sisi lain memandang pendidikan sebagai sebuah sistem total, yang dibentuk sejumlah komponen internal dan eksternal. Hanya dengan memperbaiki keseluruhan sistem pendidikan maka para profesional pendidikan dapat membuat perbaikan mutu seperti yang diminta masyarakat (Arcaro, 1995:33).

Dalam konteks bangsa Indonesia, peningkatan mutu pendidikan merupakan sasaran pembangunan di bidang pendidikan nasional dan merupakan bagian integral dari upaya peningkatan kualitas manusia Indonesia secara menyeluruh (Mulyasa, 2005:31). Banyak upaya yang telah dilakukan pemerintah maupun pihak swasta dalam meningkatkan mutu pendidikan, baik itu dilakukan melalui pendekatan struktural yang bersifta top down maupun pendekatan kultural yang bersifat bottom up. Peningkatan mutu sekolah melalui pendekatan struktural seringkali dilakukan oleh pemerintah misalnya melalui penataan ulang berbagai komponen, pengaturan, peraturanperaturan, pelatihan-pelatihan manajemen sekolah, kepemimpinan kepala sekolah, peningkatan kualitas guru dan penyempurnaan kurikulum sekolah hingga pemenuhan sarana dan prasarana sekolah. Sedangkan peningkatan mutu sekolah melalui pendekatan kultural yaitu perubahan berasal dari dalam sekolah sendiri seperti penguatan karakter siswa, gerakan literasi sekolah dan lain sebagainya.

Pada hakekatnya, berbagai upaya yang telah dilakukan pemerintah untuk meningkatkan mutu pendidikan belum menunjukkan hasil yang menggembirakan, bahkan masih banyak kegagalan ini disebabkan antara lain; masalah manajemen pendidikan yang kurang tepat, penempatan tenaga tidak sesuai dengan bidang keahliaannya (termasuk didalamnya pengangkatan kepala madrasah/sekolah yang kurang professional bahkan hanya mengutamakan nuansa politis dari pada profesionalisme), pendistribusian sarana prasarana sekolah yang kurang sesuai dengan kebutuhan sekolah, penanganan masalah bukan pada ahlinya, pemerataan kesempatan, keterbatasan anggaran yang tersedia, dan diksriminasi kebijakan pemerintah pada sekolah/madrasah swasta dan negeri, sehingga tujuan pendidikan nasional untuk mencerdaskan kehidupan bangsa melalui peningkatan mutu pada setiap jenis dan jenjang pendidikan belum dapat diwujudkan secara signifikan.

Permasalahan mutu sekolah merupakan permasalahan yang paling serius dan paling kompleks. Mutu sekolah itu menjadi cita-cita bersama seluruh pemikir, penyelenggara dan praktisi pendidikan, namun kadangkala terjadi ketidakseimbangan antara produk kerja inovasi manajemen sekolah dan aplikasinya di sekolah-sekolah. Dari sekian banyak 
upaya yang telah dilakukan menimbulkan sebuah pertanyaan ada apa sebenarnya dengan mutu sekolah sehingga banyak menghabiskan energi tetapi hasilnya belum riil dan proporsional? Untuk menjawabnya dibutuhkan analisis secara komprehensif mengenai revitalisasi sekolah berbasis budaya mutu.

\section{PEMBAHASAN}

\section{Manajemen Mutu}

Manajemen mutu menjadi suatu keharusan dalam pembenahan Lembaga pendidikan. Semua jenis kegiatan manajemen yang secara langsung maupun tidak langsung terlibat dalam pengelolaan lembaga pendidikan harus senantiasa diarahkan dan berorientasi pada pencapaian mutu. Mutu produk pendidikan akan dipengaruhi oleh sejauh mana lembaga mampu mengelola seluruh potensi secara optimal mulai dari tenaga kependidikan, peserta didik, proses pembelajaran, sarana pendidikan, keuangan dan termasuk hubungannya dengan masyarakat. Dalam hal ini, sekolah harus mampu merubah paradigma baru pendidikan yang berorientasi pada mutu semua aktifitas yang berinteraksi didalamnya, seluruhnya mengarah pencapaian pada mutu.

\section{Konsep Dasar Mutu}

Dalam Kamus Besar Bahasa Indonesia (Depdiknas, 2001: 768), mutu adalah berkaitan dengan baik buruk suatu benda; kadar; atau derajat misalnya kepandaian, kecerdasan dan sebagainya. Secara umum kualitas atau mutu adalah gambaran dan karakteristik menyeluruh dari barang atau jasa yang menunjukkan kemampuannya dalam memuaskan kebutuhan yang diharapkan atau tersirat (Depdiknas, 2002:7). Mutu mengandung makna derajat (tingkat) keunggulan suatu produk (hasil kerja/upaya baik berupa barang maupun jasa, baik yang tangible maupun yang intangible (Suryosubroto, 2004:210). Berdasarkan terminologi tersebut menunjukkan bahwa mutu adalah paduan sifat-sifat dari barang atau jasa, yang menunjukkan kemampuannya dalam memenuhi kebutuhan pelanggan, baik kebutuhan yang dinyatakan maupun yang tersirat.

Pengertian kualitas atau mutu dapat dilihat juga dari konsep secara absolut dan relatif. Dalam konsep absolut sesuatu (barang) disebut berkualitas bila memenuhi standar tertinggi dan sempurna. Artinya, barang tersebut sudah tidak ada yang melebihi. Bila diterapkan dalam dunia pendidikan konsep kualitas absolut ini bersifat elitis karena hanya sedikit lembaga pendidikan yang akan mampu menawarkan kualitas tertinggi kepada peserta didik dan hanya sedikit siswa yang akan mampu membayarnya. Sedangkan, dalam konsep relatif, kualitas berarti memenuhi spesifikasi yang ditetapkan dan sesuai dengan tujuan (fit for their purpose). Kualitas dalam konsep relatif berhubungan dengan produsen, maka kualitas berarti sesuai dengan spesifikasi yang ditetapkan pelanggan (Sallis, 1993:5153).

Terkait dengan konsep absolut dan relatif di atas, di dalam konteks pendidikan, kualitas yang dimaksudkan adalah dalam konsep relatif, terutama berhubungan dengan kepuasan pelanggan. Pelanggan pendidikan ada dua aspek, yaitu pelanggan internal dan eksternal. Pendidikan berkualitas apabila : 1) pelanggan internal (kepala sekolah, guru dan karyawan sekolah) berkembang baik fisik maupun psikis. Secara fisik antara lain mendapatkan imbalan finansial. Sedangkan secara psikis adalah bila mereka diberi kesempatan untuk terus belajar dan mengembangkan kemampuan, bakat dan kreatifitasnya; 2) pelanggan eksternal, meliputi: a) Eksternal primer (para siswa): menjadi pembelajar sepanjang hayat, komunikator yang baik dalam bahasa nasional maupun internasional, punya keterampilan teknologi untuk lapangan kerja dan kehidupan sehari- 
hari, integritas pribadi, pemecahan masalah dan penciptaan pengetahuan, menjadi warga negara yang bertanggungjawab. Para siswa menjadi manusia dewasa yang bertanggungjawab akan hidupnya, b) eksternal sekunder (orang tua, para pemimpin pemerintahan dan perusahaan); para lulusan dapat memenuhi harapan orang tua, pemerintah dan pemimpin perusahan dalam hal menjalankan tugastugas dan pekerjaan yang diberikan, dan c) eksternal tersier (pasar kerja dan masyarakat luas); para lulusan memiliki kompetensi dalam dunia kerja dan dalam pengembangan masyarakat sehingga mempengaruhi pada pertumbuhan ekonomi, kesejahteraan rakyat dan keadilan sosial (Nurkholis, 2003:68).

Dalam kerangka manajemen pengembangan mutu, usaha pendidikan tidak lain adalah merupakan usaha "jasa" yang memberikan pelayanan kepada pelangggannya yang utamanya yaitu kepada mereka yang belajar dalam lembaga pendidikan tersebut. Para pelanggan layanan pendidikan terdiri dari berbagai unsur paling tidak empat kelompok. Pertama yang belajar, bisa merupakan mahasiswa/pelajar/murid/peserta belajar yang biasa disebut klien/pelanggan primer (primary external customers). Mereka inilah yang langsung menerima manfaat layanan pendidikan dari lembaga tersebut. Kedua, para klien terkait dengan orang yang mengirimnya ke lembaga pendidikan, yaitu orang tua atau lembaga tempat klien tersebut bekerja, dan mereka ini kita sebut sebagai pelanggan sekunder (secondary external customers). Pelanggan lainnya yang ketiga bersifat tersier adalah lapangan kerja bisa pemerintah maupun masyarakat pengguna output pendidikan (tertiary external customers). Selain itu, yang keempat, dalam hubungan kelembagaan masih terdapat pelanggan lainnya yaitu yang berasal dari intern lembaga; mereka itu adalah para guru/dosen/tutor dan tenaga administrasi lembaga pendidikan, serta pimpinan lembaga pendidikan (internal customers).
Walaupun para guru/dosen/tutor dan tenaga administrasi, serta pimpinan lembaga pendidikan tersebut terlibat dalam proses pelayanan jasa, tetapi mereka termasuk juga pelanggan jika dilihat dari hubungan manajemen. Mereka berkepentingan dengan lembaga tersebut untuk maju, karena semakin maju dan berkualitas dari suatu lembaga pendidikan mereka akan diuntungkan, baik kebanggaan maupun finansial (Sallis, 1993:68).

Berdasarkan uraian di atas menunjukkan bahwa program peningkatan mutu harus berorientasi kepada kebutuhan/harapan pelanggan, maka layanan pendidikan suatu lembaga haruslah memperhatikan masing-masing pelanggan di atas. Pelanggan bisa berupa mereka yang langsung menjadi penerima produk dan jasa tersebut atau mereka yang nantinya akan merasakan manfaat produk dan jasa tersebut. Dengan perkataan lain, peningkatan mutu hendaknya berorientasi pada kebutuhan dan kepuasan stakeholders, baik stakeholder internal maupun stakeholders eksternal. Kepuasan dan kebanggaan dari pelanggan sebagai penerima manfaat layanan pendidikan harus menjadi acuan bagi program peningkatan mutu layanan pendidikan.

\section{Mutu Pendidikan}

Berdasarkan konsepsi dasar dari makna mutu maka mutu pendidikan adalah gambaran dan karakteristik menyeluruh jasa pelayanan pendidikan secara internal maupun eksternal yang menunjukkan kemampuannya memuaskan kebutuhan yang diharapkan atau yang tersirat mencakup input, proses, dan output pendidikan. Dalam konteks mutu pendidikan, pada hakekatnya tujuan lembaga pendidikan adalah untuk menciptakan dan mempertahankan kepuasan para pelanggan dan dalam kepuasan pelanggan ditentukan oleh stakeholder lembaga pendidikan tersebut. Oleh karena hanya dengan memahami 
proses dan kepuasan pelanggan maka lembaga dapat menyadari dan menghargai kualitas. Semua usaha atau kegiatan manajemen mutu harus diarahkan pada suatu tujuan utama, yaitu kepuasan pelanggan, apa yang dilakukan manajemen tidak ada gunanya bila tidak melahirkan kepuasan pelanggan.

Mutu pendidikan dapat dilihat dalam tiga hal, yakni input (masukan), proses, dan output (keluaran) (Rohiat, 2009:52). Input pendidikan adalah segala sesuatu yang harus tersedia karena dibutuhkan untuk berlangsungnya proses. Sesuatu yang dimaksud berupa sumberdaya dan perangkat lunak serta harapan-harapan sebagai pemandu bagi berlangsungnya proses. Input sumberdaya manusia meliputi (kepala sekolah, guru, karyawan, dan peserta didik) dan sumberdaya selebihnya (peralatan, perlengkapan, uang dan bahan, dsb.). Input perangkat lunak meliputi (struktur organisasi sekolah, peraturan perundang-undangan, deskripsi tugas, rencana, program dsb.) Input harapan berupa (visi, misi, tujuan, dan sasaransasaran yang ingin dicapai sekolah). Oleh karena itu, tinggi rendahnya mutu input dapat diukur dari tingkat kesiapan input. Makin tinggi tingkat kesiapan input, makin tinggi pula mutu input tersebut.

Proses pendidikan merupakan berubahnya sesuatu menjadi sesuatu yang lain. Dalam pendidikan berskala mikro (sekolah), proses yang dimaksud adalah proses pengambilan keputusan, proses pengelolaan program, proses pembelajaran dan proses monitoring dan evaluasi. Proses dikatakan bermutu tinggi apabila pengkoordinasian dan penyerasian input dilakukan secara harmonis sehingga menciptakan pembelajaran yang menyenangkan (enjoyable learning).

Output pendidikan adalah merupakan kinerja sekolah. Kinerja sekolah adalah prestasi sekolah yang dihasilkan dari proses sekolah. Kinerja sekolah dapat diukur dari (kualitasnya, efektivitasnya, produktivitasnya, efisiensinya, inovasinya, kualitas kehidupan kerjanya dan moral kerjanya). Kualitas sekolah bermutu tinggi jika prestasi sekolah, khususnya prestasi belajar peserta didik menunjukkan pencapaian yang tinggi dalam (a) prestasi akademik, (nilai ulangan umum, nilai Ujian Nasional, karya ilmiah, lomba akademik dan (b) prestasi non akademik (IMTAQ, kejujuran, kesopanan, olahraga, kesenian, keterampilan kejuruan dan kegiatan pengembangan diri).

Pada tingkat sekolah, mutu dapat dirumuskan sebagai tingkat keberhasilan sekolah dalam mewujudkan output yang diharapkan. Persaoalannya adalah hal-hal apa saja yang dapat disebut sebagai indikator dari tingkat keberhasilan sekolah?. Umumnya orang menganggap suatu sekolah cukup berhasil jika para lulusannya (sekurangnya sebagian besar diantaranya) memiliki karakteristik yang diharapkan, baik meliputi aspek kemampuan intelektual/akademik, maupun aspek watak dan keterampilan. Sebagai contoh, sebuah SMA dapat dianggap berhasil jika banyak lulusannya diterima di perguruan tinggi yang baik, karena ini sesuai dengan misi yang diemban oleh SMA, yaitu mempersiapkan peserta didik untuk memasuki perguruan tinggi. Atau sekurangnya, sebuah SMA dapat dikatakan berhasil jika berdasarkan evaluasi akhir para lulusannya memenuhi persyaratan pengetahuan, keterampilan dan watak yang diharapkan. Selain itu, ada pula yang menganggap tingkat kepuasan konsumen, yaitu peserta didik, orang tua pihak lain yang memiliki harapan terhadap sekolah, sebagai salah satu indikator dari mutu sekolah (Jahja Umar, 2011: 40).

Di dalam kerangka mutu pendidikan, antara input/masukan, proses, dan output atau hasil pendidikan saling berhubungan. Artinya, untuk menghasilkan output pendidikan yang bermutu, dipengaruhi oleh proses pendidikannya, dan proses pendidikan yang bermutu akan dapat menghasilkan output yang lebih bermutu bilamana didukung oleh input pendidikan yang bermutu pula. Sekolah dapat dikatakan 
bermutu jika input, proses dan output pendidikannya dapat memenuhi persyaratan yang dituntut oleh pengguna jasa pendidikan, baik internal maupun eksternal. Dalam hal ini, manajemen mutu sekolah merupakan kemampuan sekolah dalam mendayagunakan sumber daya pendidikan baik sumber daya manusia maupun non manusia untuk meningkatkan kemampuan input, proses dan output pendidikan guna memenuhi persyaratan yang dituntut oleh pengguna jasa pendidikan. Dengan demikian, seluruh kegiatan manajemen diarahkan pada tuntutan dan kepuasan pelanggan atau pengguna jasa pendidikan (stakeholders). Bila performance-nya baik dan dapat melebihi persyaratan yang dituntut oleh stakeholders/user pendidikan, maka sekolah tersebut dapat dikatakan unggul.

Formula input, proses dan output pendidikan dalam upaya mewujudkan hasil pendidikan yang unggul/istimewa dapat dilihat pada tabel berikut:

Tabel 1. Korelasi Antara Input, Proses dan Output dalam Pendidikan

\begin{tabular}{|c|c|c|c|}
\hline No & $\begin{array}{l}\text { Keadaan } \\
\text { Input }\end{array}$ & $\begin{array}{l}\text { Keadaan } \\
\text { Proses }\end{array}$ & $\begin{array}{l}\text { Keadaan } \\
\text { Output }\end{array}$ \\
\hline 1 & Baik & Sangat Baik & $\begin{array}{l}\text { Unggul/Istim } \\
\text { ewa }\end{array}$ \\
\hline 2 & Baik & Baik & Pasti Baik \\
\hline 3 & Baik & Sedang & $\begin{array}{l}\text { Menurun } \\
\text { menjadi agak } \\
\text { baik }\end{array}$ \\
\hline 4 & Baik & Jelek & Sedang \\
\hline 5 & Sedang & Istimewa & Baik Sekali \\
\hline 6 & Sedang & Baik & Meningkat \\
\hline 7 & Sedang & Sedang & Tetap \\
\hline 8 & Sedang & Jelek & Makin Jelek \\
\hline 9 & Rendah & $\begin{array}{l}\text { Sangat } \\
\text { Istimewa }\end{array}$ & Baik \\
\hline 10 & Rendah & Baik & Sedang \\
\hline 11 & Rendah & Sedang & $\begin{array}{l}\text { Cenderung } \\
\text { sedikit } \\
\text { meningkat }\end{array}$ \\
\hline 12 & Rendah & Jelek & Pasti Rendah \\
\hline
\end{tabular}

Sumber: Mujamil Qomar (2007: 207-209)

Tabel di atas menunjukkan bahwa sekolah tidak boleh mengabaikan dan menganggap remeh proses pembelajaan dan proses pendidikan di sekolah karena untuk mencapai output yang unggul/istimewa dan berkemajuan, proses pendidikan lebih berpengaruh dominan daripada input pendidikan. Apapun dan bagaimanapun input sekolah, kontribusi proses pendidikan sangat besar dalam menghasilkan output yang unggul. Hal ini menuntut perubahan mindset kepala sekolah dan guru yang menganggap rendahnya output sekolah dititikberatkan pada inputnya yang rendah, padahal sesungguhnya setiap anak didik memiliki potensi tumbuhkembang sehingga baik tidaknya hasil tumbuhkembang tersebut, dominan merupakan hasil dari proses pendidikannya. Oleh karena itu, para pengelola pendidikan harus menguatkan mutu prosesnya ketimbang mempersoalkan mutu inputnya. Hal ini membutuhkan komitmen yang tinggi dan kerja keras dari pengelola, tenaga kependidikan, terutama para guru di sekolah.

\section{Budaya Mutu}

Bermutu dan berkeunggulan merupakan bagian yang tak terpisahkan dari jaminan mutu sekolah. Sekolah yang bermutu tentu sekolah yang berkeungulan baik unggul kompetitif maupun komparatif, dan sekolah yang memiliki kedua keunggulan tersebutlah yang dapat mendapatkan kepercayaan masyarakat dan tidak akan ditinggal oleh masyarakat karena sebagai jaminan dari mutu sekolah. Di sisi yang lain budaya berkeunggulan merupakan perintah agama (Islam) untuk berlombalomba dalam kebaikan (fastabiqu al-Khairat) karena manusia yang memiliki keunggulan kebaikanlah yang mendapat derajat yang lebih tinggi.

Sekolah yang bermutu tentu memiliki budaya mutu yang tinggi. Setiap elemen sekolah berkesadaran mutu dan membudayakan mutu sehingga pengelolaan sekolah harus berbasis pada mutu pula. Mutu menjadi cita-cita sekolah dan untuk mencapai cita-cita tersebut maka semua 
program kegiatan sekolah harus berdasarkan pada standar mutu yang telah ditetapkan oleh pihak sekolah.

Menurut Syaiful Sagala (2007:170) peningkatan mutu sekolah diperoleh melalui dua strategi, yaitu peningkatan mutu pendidikan yang berorientasi akademis untuk memberi dasar minimal dalam perjalanan yang harus ditempuh mencapai mutu pendidikan yang dipersyaratkan oleh tuntutan zaman, dan peningkatan mutu pendidikan yang berorientasi pada keterampilan hidup yang esensial yang dicakupi oleh pendidikan yang berlandasan luas, nyata dan bermakna. Dalam konteks ini, ada dua peran utama yang harus dimainkan pihak sekolah, yaitu mendidik pelajar dengan beragam mata pelajaran/keterampilan kognitif dan pengetahuan, dan mendidik pelajar dalam pengembangan individu dan social (Fullan, 1982:10). Dalam pandangan Fullan, sekolah efektif (bermutu) adalah sekolah yang mampu mengantarkan dan memfasilitasi peserta didik sehingga potensi akademis dan perkembangan individu-sosial dapat diaktualisasikan secara optimal (Mohamad Ali, 2009: 122).

Dalam memaikan kedua peran utama tersebut, kepala sekolah dapat menciptakan suasana akademis yang baik. Kepala sekolah dapat melakukan langkahlangkah yang konkrit untuk membantu pengembangan orientasi akademis dan non akademis. Menurut Davis dan Thomas (2006:29-30) terdapat delapan kategori yang dapat dilakukan oleh kepala sekolah, yaitu:

Pertama, kepala sekolah dapat memainkan peran aktif dalam meningkatkan kesadaran perlunya perbaikan sekolah dan harapan prestasi yang lebih tinggi dan pencapaian konsensus untuk perubahan tersebut. Hal ini dimaksudkan agar peningkatan mutu sekolah merupakan hasil dari konsensus bersama sehingga masing-masing elemen sekolah memiliki kesadaran dan komitmen bersama terhadap mutu yang diharapkan.
Kedua kepala sekolah dapat aktif dalam penciptaan perbaikan yang konkrit itu sendiri. Kepala sekolah juga dapat mendatangkan keterlibatan orang tua dalam upaya pengajaran sekolah. Hal ini untuk membangun sinergisitas kerjasama antara sekolah dengan orang tua dalam mendidik siswa di sekolah dan di rumah.

Ketiga, kepala sekolah dapat menciptakan sistem hadiah untuk siswa dan guru yang mendukung orientasi akademis dan merangsang keunggulan dalam penampilan siswa dan guru. Hal ini sebagai wujud apresiasi, perhatian, penghargaan dan motivasi serta kepedulian dari sekolah pada siswa dan guru yang berprestasi.

Keempat, tingkah laku sentral kepala sekolah yang efektif adalah monitoring perkembangan siswa, khususunya seperti tercermin dalam nilai tes tiap tingkatan, tiap kelas, dan tiap siswa. Tindakan ini secara intrinsik mencerminkan fokus dan nilai akademis. Monitoring ini diperlukan untuk memantau sekaligus mengantisipasi atas gradasi nilai siswa sehingga dapat dilakukan tindakan preventif agar nilai siswa tetap berada dalam tingkatan yang baik.

Kelima, kepala sekolah dapat memperoleh sumber-sumber material dan personal yang diperlukan untuk pengajaran yang efektif dan menggunakannya secara kreatif sesuai dengan prioritas akademik. Dalam hal ini, kualitas mengajar guru selalu ditingkatkan baik secara personal maupun kolektif di dalam sekolah melalui forumforum seminar, workshop, lokakarya, MGMP, dan sebagainya.

Keenam, kepala sekolah bertanggung jawab terhadap penciptaan lingkungan yang tertib dan aman. Ada banyak saran yang berkaitan dengan penciptaan lingkungan sekolah yang dapat dilakukan oleh kepala sekolah, antara lain: a) menjaga proses belajar mengajar dari interupsi atau gangguan. Misalnya membatasi sistem panggilan yang bersifat umum, seperti membatasi panggilan telepon yang tidak penting untuk waktu-waktu tertentu; b) mengembangkan kebijakan yang jelas dan 
konsisten dan mempromosikan pengikut sesuai dengan aturan dan peraturan; c) memberdayakan partisipasi siswa dalam pendiptaan lingkungan akademik melalui pengkondisian sejumlah siswa untuk ikut berpartisipasi. Misalnya dalan kegiatan club akademik, kompetisi seperti computer, bahasa, dan olahraga; d) mengungkapkan minat dan kesenangan siswa melalui penelusuran riwayat kesehatan siswa, keluarga, kelas, aktivitas dan hal-hal lain yang berkenaan dengan kehidupan social siswa; e) displin, jika perlu mengeluarkan siswa, atau kebijakan lain menghadapi siswa yang suka mengintimidasi kawan, membuat kekacauan, dan keributan.

Ketujuh, kepala sekolah dapat memonitor faktor-faktor lain yang terkait dengan prestasi, faktor yang terkait dengan perbaikan yang secara implisit menekankan suasana/budaya akademik. Hal ini penting dilakukan kepala sekolah sebagai bentuk kesiagaan dalam menjaga prestasi sekolah.

Kedelapan, fungsi utama kepala sekolah yang efektif adalah mengamati guru dalam kelas dan merundingkan dengan mereka tentang cara menangani masalah dan perbaikan pengajaran. Dalam hal ini dilakukan pula tindak lanjutnya untuk mengatasi masalah guru dalam pembelajaran, karena pembelajaran yang bermutu akan menjadikan hasil pembelajaran yang bermutu pula.

Kedelapan tindakan di atas membutuhkan kerja keras dan komitmen dari kepala sekolah. Tentu yang dibutuhkan adalah kepala sekolah yang punya semangat yang kuat, energik dan gesit, tekun dan berani pada tantangan progresif untuk kemajuan sekolah. Anwar Hasnun (2010:2627) menambahkan bahwa untuk menciptakan sekolah yang bermutu, kepala sekolah dapat melakukan hal-hal sebagai berikut: a) rancang visi, misi dan tujuan sekolah dengan baik; b) susun program sekolah yang terukur sesuai kondisi sekolah dan kondisi masyarakat; c) sekolah membuat program harian, mingguan, bulanan, tahunan dan tetapkan siapa melakukannya; d) wakil kepala sekolah, guru, guru Pembina, guru bimbingan, bekerja sesuai tugas berdasarkan program yang dibuat; e) semua guru dilibatkan dan dimotivasi untuk berpikir kreatif dan melakukan inovasi dalam kegiatan pembelajaran; f) bangun kerjasama yang harmonis dengan orang tua siswa, masyarakat, dunia usaha dan pihak-pihak terkait untuk memperoleh dukungan dana; g) lakukan supervise kelas secara periodic, h) adakan kegiatan KKG, MGMP, Workshop, diskusi, seminar kelas, dan kegiatan ilmiah dengan melibatkan pihakpihak terkait; i) ciptakan keharmonisan dan kekeluargaan, kenyamanan dan keamanan di sekolah; j) hindari guru membuat kelompok tertentu, sifat apriori dan menunggu perintah; dan k) lakukan evaluasi, penilaian dan program tindak lanjut, perbaikan dan pengayaan.

Di dalam pencapaian mutu sekolah, setiap sekolah berorientasi pada dua keunggulan mutu, yaitu keunggulan kompetitif dan keunggulan komparatif. Kedua paradigma keunggulan tersebut menjadi misi dan tujuan sekolah untuk mencapainya. Keunggulan kompetitif lebih berorientasi pada keunggulan akademik, maka masing-masing sekolah dengan standar mutu yang sama berloma-lomba memenangkan persaingan akademik dalam berbagai arena seperti ujian nasional. Sekolah yang mampu bersaing secara akademik bahkan dapat mengungguli sekolah lainnya akan dipandang oleh masyarakat memiliki mutu akademik yang unggul. Oleh karena itu dalam paradigma keunggulan kompetitif lebih mengutamakan kualitas ketimbang kuantitas. Sedangkan keunggulan komparatif lebih berorientasi pada keunggulan non akademik. Masingmasing sekolah memiliki keunggulan komparatif yang sangat variatif dan disini dituntut disparitas keunggulannnya yang sesuai dengan harapan masyarakat.

Sekolah sebagai lembaga pendidikan dan pembelajaran harus dapat menggapai kedua keunggulan itu, karena dalam 
pandangan masyarakat modern, sekolah yang mampu bersaing dan mampu menunjukkan keunggulannyalah yang dapat memberikan kepuasan pada masyarakat sebagai hasil dari proses pendidikan di sekolah. Persaingan sekolah Negeri dan sekolah swasta di dalam mendapatkan kepercayaan masyarakat dimana masingmasing sekolah dituntut untuk dapat membuktikan keunggulannya pada masyarakat sebagai stakeholders sekolah. Oleh karena itu menurut Hendro Widodo (2017) sekolah harus membudayakan keunggulan kompetitif dan komparatif dengan melakukan berbagai strategi, diantaranya:

$$
\text { Pertama, menggali dan }
$$

mengembangkan potensi siswa. Potensi peserta didik sangatlah holistik, dan setiap siswa memiliki potensi emas yang berbedabeda sehingga menjadi tugas sekolah untuk mengembangkannya. Pengembangan potensi tersebut dilakukan oleh pihak sekolah dengan memberdayakan semua potensi sekolah dan disinilah diuji kemampuan kepala sekolah sebagai pimpinan sekolah dalam memberdayakan sumberdaya sekolah. Kepala sekolah yang mampu memberdayakan maka akan menghasilkan siswa-siswa yang berkeunggulan, sementara kepala sekolah yang tidak mampu memberdayakan sumberdaya sekolahnya akan menghasilkan siswa yang kurang berkeunggulan. Pembinaan dan pengembangan potensi secara intensif dan berkelanjutan sebagai wujud komitmen berkeunggulan ini dapat dilakukan dengan bersinergi dengan orang tua maupun pihak luar sekolah.

Kedua, sekolah memfasilitasi keunggulan potensi siswa dalam ajang kompetisi internal dan eksternal. Berkompetisi sebagai bentuk aktualisasi siswa di dalam sekolah dan di luar sekolah. Budaya kompetisi antar siswa yang diwujudkan dalam budaya berprestasi baik akademik maupun non akademik harus difasilitasi oleh sekolah. Budaya berprestasi merupakan bentuk budaya sekolah yang menjadi poin utama di setiap sekolah. Prestasi yang diperoleh oleh sekolah juga dapat digunakan sebagai indikator keberhasilan sekolah. Semakin banyak prestasi yang diraih oleh sekolah maka dapat mengembangkan semangat untuk berprestasi baik akademik maupun non akademik. Budaya prestasi akademik yang menjadi barometer keunggulannya nilai ujian nasional dipandang oleh sekolah sebagai target yang harus tercapai sehingga upaya gerakan sekolah dalam bidang akademik diarahkan pada pencapaian nilai tertinggi. Sementara budaya berprsetasi non akademik menjadi diferensiasi dengan sekolah lain sehingga dapat menjadi keungulan komparatif sekolah.

Ketiga, sekolah melakukan diferensiasi keunggulan dengan sekolah lain. Berdasarkan penggalian potensi yang ada di sekolah, pihak sekolah harus mampu mencari cela yang tidak menjadi keunggulan sekolah lain. Pihak sekolah memberdayakan kelebihan atau keungulan yang dimiliki oleh sumberdaya sekolah dan menggarap program keunggulan tersebut sehingga menjadi keunggulan komparatif yang dibanggakan oleh sekolah dan menjadi ciri khusus sekolah. Dalam hal ini, berlaku istilah lakukan yang tidak biasa dilakukan oleh orang lain maka akan menjadi yang luar biasa, tetapi jika melakukan yang biasa saja, maka akan menjadi yang biasa-biasa saja".

$$
\text { Keempat, sekolah perlu }
$$

memperbanyak jaringan kerjasama dengan berbagai pihak untuk menyiapkan keunggulan sekolahnya dan melakukan branding sekolah. Sekolah dapat melakukan jejaring antar jenjang maupun sesama jenjang, baik pada sekolah negeri maupun pada sekolah swasta sehingga akan semakin terbuka peluang kompetisi dan komparasi antar sekolah. Sekolah swasta dalam satu yayasan misalnya, dapat berkolaborasi dalam membangun jejaring untuk mencapai keunggulan konmparatifnya dengan sekolah lainnya. Membangun jejaring kerjasama juga sebagai bentuk image building bagi sekolah untuk mendapatkan kepercayaan 
masyarakat sehingga akan terbangun dengan baik institutional building dan trust building sebagai pilar keunggulan sekolah.

Keempat langkah strategis tersebut sebagai alternatif sekolah dalam membudayakan keunggulan kompetitif dan komparatif. Keunggulan adalah suatu keniscayaan bagi sekolah, masing-masing sekolah harus berlomba-lomba mencapai dan menunjukkan keunggulannya karena keunggulan merupakan bentuk nyata hasil dari suatu proses pendidikan di sekolah dan dengan keunggulannya pulalah masingmasing sekolah akan dapat lebih eksis dalam mendapatkan hati masyarakat.

\section{Jaminan Budaya Mutu}

Di dalam kerangka mutu sekolah, setiap sekolah diminta untuk dapat memberikan jaminan ataupun garansi mutu terhadap masyarakat (orang tua) sebagai stakeholders pendidikan. Orang tua saat ini mulai cerdas dalam mencari dan menyekolahkan anak didik, sekolah yang dapat memberikan jaminan mutulah yang akan dicari meskipun dalam wilayah geografis yang terpencil dari perkotaan. Di sisi yang lain, bentuk kecerdasan orang saat ini ialah orang tua tidak merasa berat untuk mengeluarkan biaya pendidikan yang lebih tinggi asalkan sekolah dapat memberikan jaminan mutunya. Artinya, bagi orang tua, suatu jaminan mutu pendidikan anakanaknya adalah hal yang utama, produk atau hasil pendidikan sekolah dapat memberikan kepuasan pada orang tua.

Oleh karenanya, agar hasil pendidikan sekolah bermutu dan memberikan kepuasan kepada orang tua, setiap sekolah harus dapat memberikan jaminan mutu sekolahnya. Ada tiga aspek jaminan mutu sekolah, yaitu:

Pertama, leading and managing. Kepala sekolah sebagai lokomotif kemajuan sekolah memiliki peran utama sebagai leader dan manager. Kedua peran ini ibarat dua sisi mata uang yang tidak dapat dipisahkan. Sebagai leader (pemimpin), kepala sekolah berperan memberikan pengaruh pada warga sekolah dan menggerakkan sumber daya sekolah agar dapat memainkan perannya secara profesional dan proporsional untuk mencapai tujuan sekolah. Scheerens dan Bosker (1997: 207) berpendapat bahwa yang membedakan antara sekolah yang kualitasnya baik dengan sekolah yang kualitasnya biasa adalah kepemimpinan kepala sekolahnya.

Kepala sekolah merupakan motor penggerak, penentu arah kebijakan sekolah, yang akan menentukan bagaimana tujuantujuan sekolah dan pendidikan pada umumnya direalisasikan. Mulyasa (2004:126) menegaskan bahwa kepemimpinan kepala sekolah yang efektif dapat dilihat berdasarkan kriteria berikut: 1) mampu memberdayakan guru-guru untuk melaksanakan proses pembelajaran dengan baik, lancar, dan produktif; 2) dapat menyelesaikan tugas dan pekerjaan sesuai dengan waktu yang telah ditetapkan; 3) mampu menjalin hubungan yang harmonis dengan masyarakat sehingga dapat melibatkan mereka secara aktif dalam rangka mewujudkan tujuan sekolah dan pendidikan; 4) berhasil menerapkan prinsip kepemimpinan yang sesuai dengan tingkat kedewasaan guru dan pegawai lain di sekolah; 5) bekerja dengan tim manajemen; serta 6) berhasil mewujudkan tujuan sekolah secara produktif sesuai dengan ketentuan yang telah ditetapkan.

Selain peran sebagai pemimpin, kepala sekolah juga mempunyai peran sebagai manajer. Sebagai manajer, kepala sekolah berkewajiabn menjaga stabilitas sekolah agar sesuai dengan koridor jalan regulasi yang telah ditetapkan baik oleh pemerintah maupun yayasan bagi sekolah swasta. Kepala sekolah sebagai manajer berperan melakukan perencanaan, pengorganisasian, penggerakkan, dan pengawasan semua program sekolah. Guna mencapai keberhasilannya dalam tugas manajernya, menurut Katz (Sudarwan Danim, 2002:134) ada tiga komponen keterampilan yang harus dimiliki dan 
dikuasai oleh seorang kepala sekolah, yaitu: 1) technical skill (kemampuan teknik), buman skill (kemampuan hubungan kemanusiaan), dan conceptual skill (kemampuan konseptual). Kemampuan teknik adalah kemampuan yang berhubungan erat dengan penggunaan alat-alat, prosedur, metode dan teknik dalam suatu aktivitas manajemen secara benar (working with things). Sedangkan, kemampuan hubungan kemanusiaan merupakan kemampuan untuk menciptakan dan membina hubungan baik, memahami dan mendorong orang lain sehingga mereka bekerja secara suka rela, tiada paksaan dan lebih produktif (working with people). Kemampuan konseptual adalah kemampuan mental untuk mengkoordinasikan, dan memadukan semua kepentingan serta kegiatan organisasi.

Berdasarkan uraian di atas dapat ditegaskan bahwa ada dua fokus garapan kepala sekolah sebagai manajer, yaitu kepala sekolah memiliki keterampilan manajerial yang baik dan mampu melaksanakan fungsi manajemen sekolah dengan benar. Oleh karena itu, efektifitas manajemen sekolah sangat ditentukan oleh kemampuan manajerial kepala sekolah serta kemampuanya sebagai pemimpin sekolah yang dapat memanfaatkan sumber-sumber potensial sekolah secara efektif dan efisien guna ketercapaian mutu sekolah.

Kedua, learning process. Proses belajar siswa di sekolah merupakan kegiatan inti dari kegiatan di sekolah. Disinilah para siswa memperoleh sejumlah pengalaman belajar baik yang bersifat kognitif, afektif dan psikomotorik. Ketiga pengalaman belajar tersebut diterima siswa secara simultan dalam kegiatan belajar di sekolah, dan sebagai hasil dari pengalaman belajar itu, diharapkan siswa menjadi anggun moralnya, unggul intelektualnya, dan mengamalkannya dalam kehidupan yang memberikan nilai positif pada dirinya dan orang lain. Oleh karena itu, sekolah harus dapat memberikan jaminan akhir dari sebuah proses belajar siswa di sekolah, sehingga semua pemberian pengalaman belajar siswa dilaksanakan dengan sebenarbenarnya. .

Peran kepala sekolah dalam learning process ini ialah memastikan bahwa siswa dapat belajar dengan nyaman dan menyenangkan, iklim belajar yang kondusif, dan memonitor kemajuan belajar siswa. Edmonds (Kompri, 2017:116) menegaskan bahwa karakteristik sekolah yang efektif, yaitu kepala sekolah dan guru memiliki komitmen dan perhatian yang tinggi terhadap perbaikan mutu pembelajaran dan guru-guru memiliki harapan yang tinggi untuk mendukung pencapaian prestasi siswa.

Ketiga, teaching procces. Kegiatan mengajar disini ditekankan pada tugas mengajar guru. Proses mengajar guru sangat erat pengaruhnya pada hasil belajar siswa. Guru yang baik dalam mengajar (dari persiapan, inti, dan penutup) akan menghasilkan luaran belajar yang bermutu. Disinilah pentingnya penguatan proses pembelajaran, karena dasar utama sekolah yang bermutu adalah pembelajaran yang bermutu pula.

Peran guru dalam menciptakann pembelajaran yang bermutu sangatlah penting. Dalam hal ini guru selalu dituntut untuk meningkatkan kompetensi pedagogik dan profesionalnya. Ahmad Rizal, dkk (2009:17) menyatakan bahwa seorang guru professional bak seorang chef ahli yang dapat diminta untuk membuat masakan jenis apapun sepanjang bahan dan peralatannya tersedia. Seorang chef ahli bahkan bisa membuat masakan yang enak meski bahan dan peralatannya terbatas. Oleh karen itu, kepala sekolah harus dapat memastikan bahwa mutu gurunya baik. Kepala sekolah memastikan bahwa pembelajaran di kelas berlangsung dengan baik, tidak terjadi jam kosong, atau guru terlambat masuk kelas dan sebagainya, karena menurut Fink dan Resnick (Stronge, 2008:13) di sekolahsekolah yang efektif, kepala sekolah mampu menilai kualitas pengajaran dan berbagi 
pengetahuan tentang pengajaran secara mendalam dengan para guru.

\section{Strategi Meningkatkan Mutu Sekolah}

Dalam kerangka memenuhi tuntutan dan kepuasan pelanggan atau pengguna jasa pendidikan diperlukan strategi yang jitu. Strategi tersebut diharapkan dapat mengatasi masalah rendahnya mutu pendidikan melalui optimalisasi sumber daya sekolah yang secara langsung dapat meningkatkan mutu sekolah.

Mutu pendidikan harus diupayakan untuk mencapai kemajuan yang dilandasi oleh suatu perubahan terencana. Meningkatkan mutu sekolah dapat pula ditingkatkan melalui beberapa cara, seperti 1) meningkatkan ukuran prestasi akademik melalui ujian nasional atau ujian daerah yang menyangkut kompetensi dan pengetahuan, memperbaiki tes bakat (Scolastik Aptitude Test), sertifikasi kompetensi dan profil portofolio (portofolio profile), 2) membentuk kelompok sebaya untuk meningkatkan gairah pembelajaran melalui belajar secara kooperatif (coopperative learning), 3) menciptakan kesempatan baru di sekolah dengan mengubah jam sekolah menjadi pusat belajar sepanjang hari dan tetap membuka sekolah pada jam-jam libur, 4) meningkatkan pemahaman dan penghargaan belajar melalui penguasaan materi (mastery learning) dan penghargaan atas pencapaian prestasi akademik, 5) membantu siswa memperoleh pekerjaan dengan menawarkan kursus-kursus yang berkaitan dengan keterampilan memperoleh pekerjaan (Nurkholis, 2003:. 78-79).

Upaya peningkatan mutu pendidikan dapat ditempuh dalam menerapkan Total Quality Management (TQM). TQM merupakan suatu pendekatan dalam menjalankan usaha yang mencoba untuk memaksimumkan daya saing organisasi melalui perbaikan terus menerus atas produk, jasa, manusia, proses dan lingkungan. Namun pendekatan TQM hanya dapat dicapai dengan memperhatikan karakteristiknya, yaitu: 1) fokus pada pelanggan baik internal maupun eksternal, 2) memiliki obsesi yang tinggi terhadap kualitas, 3) menggunakan pendekatan ilmiah dalam pengambilan keputusan dan pemecahan masalah, 4) memiliki komitmen jangka panjang, 5) membutuhkan kerjasama tim, 6) memperbaiki proses secara berkesinambungan, 7) menyelenggarakan pendidikan dan pelatihan, 8) memberikan kebebasan yang terkendali, 9) memiliki kesatuan tujuan, dan 10) adanya keterlibatan dan pemberdayaan karyawan (Kambey, 2004: 34-45).

Strategi di atas menunjukkan bahwa program peningkatan mutu harus berorientasi kepada kebutuhan dan harapan pelanggan/stakeholder. Kepuasan dan kebanggaan dari mereka sebagai penerima manfaat layanan pendidikan harus menjadi acuan bagi program peningkatan mutu layanan pendidikan. Pemberian kepuasan secara terus menerus dan berkesinambungan mengindikasikan adanya proses layanan pendidikan yang harus selalu melakukan inovasi dan pengembangan, karena kepuasan stakeholder merupakan proses yang selalu berubah. Penekanan pada pemberian kepuasan kepada stakeholder merupakan hal yang harus dilakukan oleh setiap lembaga pendidikan Islam, jika lembaga tersebut menginginkan untuk mampu bersaing. Hal ini menuntut pengelola lembaga pendidikan Islam harus dapat membaca kecenderungan masyarakat ke depan sehingga dapat menentukan strategi apa yang dapat dilakukan terkait dengan penjaminan mutu pendidikan.

Keberhasilan sekolah diukur dari tingkat kepuasan pelanggan baik internal maupun eksternal. Sekolah dikatakan berhasil jika mampu memberikan layanan sama atau melebihi harapan pelanggan. Dilihat dari jenis pelanggannya, sekolah dikatakan berhasil jika:

Siswa puas dengan layanan sekolah. Misalnya, puas dengan pelajaran yang diterima, puas dengan perlakuan guru 
maupun pimpinan, dan puas dengan fasilitas yang disediakan sekolah. Intinya, siswa menikmati situasi sekolah. Orangtua puas dengan layanan terhadap anaknya maupun layanan kepada orangtua. Misalnya, puas karena menerima lapiran periodic tentang perkembangan siswa maupun program-program sekolah. Pihak pemakai. Penerima lulusan (perguruan tinggi, industri, dan masyarakat) puas karena menerima lulusan dengan kualitas yang sesuai dengan harapan. Guru dan karyawan puas dengan pelayanan sekolah. Misalnya, dalam pembagian kewajiban kerja, hubungan antarguru/karywan/pimpinan, honorarium/gaji, dan sebagainya (Depdikbud, 1998:151).

Untuk mewujudkan keberhasilan tersebut, menurut Mujamil Qomar (2007:205) ada beberapa hal yang harus diperhatikan oleh manajer atau pimpinan sekolah, yaitu:

Berusaha

memuaskan siswa/santri/mahasiswa dengan melengkapi fasilitas belajar, meningkatkan profesionalisme guru/ustadz/dosen, mengondisikan lingkungan belajar yang kondusif, memberikan jaminan rasa aman, nyaman dan tenteram, serta menghadirkan situasi pembelajaran yang menghibur. Berusaha memuaskan pegawai dengan cara meningkatkan kesejahteraan, perhatian, dan hubungan harmonis dengan mereka, memperlancar peningkatan karier mereka, dan semakin memberdayakan potensi mereka melalui berbagai pelatihan, workhshop, diskusi, seminar, kursus, dan lain sebagainya. Berusaha meyakinkan orangtua siswa/santri/mahasiswa bahwa putra-putrinya terjamin keamanannya, kemampuan intelektualnya, kepribadiannya, keimanannya, dan akhlaknya melalui berbagai program bimbingan yang dilaksanakan oleh lembaga pendidikan (sekolah). Di samping itu, juga berusaha melibatkan orangtua untuk mendeteksi perkembangan anak dan jenis-jenis program bimbingan. Berusaha membuktikan kemampuan siswa/santri/mahasiswa maupun para alumni yang andal kepada para pengguna lulusan baik lembaga yang lebih atas, perguruan tinggi, industri, maupun negara. Berusaha mewujudkan lingkungan lembaga pendidikan yang benarbenar Islami, cerdas anggun, asri, dan memesona kepada masyarakat luas.

Upaya mewujudkan keberhasilan di atas merupakan langkah strategik yang dapat dilakukan oleh pengelola sekolah. Hal demikian dilakukan untuk memberikan kepuasan terhadap pelanggan pendidikan, baik internal maupun eksternal sebagai tujuan utama dari manajemen mutu sekolah. Namun perlu pula penulis tegaskan bahwa untuk menciptakan sekolah yang bermutu sebagaimana yang diharapkan banyak orang atau masyarakat bukan hanya menjadi tanggungjawab sekolah, tetapi merupakan tanggungjawab dari semua pihak termasuk didalamnya orang tua dan dunia usaha sebagai customer internal dan eksternal dari sekolah.

\section{KESIMPULAN}

Peningkatan mutu sekolah merupakan pengelolaan secara menyeluruh sumber daya sekolah dengan mempergunakan dan memberdayakannya secara optimal berdasarkan standar mutu yang telah ditentukan oleh sekolah. Semua program dan kegiatan manajemen sekolah diarahkan pada suatu tujuan utama, yaitu kepuasan pelanggan (stakeholders) baik internal maupun eksternal karena kedua pelanggan tersebut memiliki hubungan timbal balik dan saling membutuhkan. Akhirnya, untuk menjadikan sekolah yang bermutu maka semua komponen yang ada di sekolah harus berkesadaran mutu dan membudayakan mutu dalam aktivitas sekolah serta manajemen sekolah yang berbasis pada mutu. 


\section{DAFTAR PUSTAKA}

Ali, Mohamad. (2009). Menabur Benib Sekolab Unggul di Muhammadiyah, Yogyakarta: Suara Muhammadiyah.

Arcaro, S. Jerome. (1995). Quality in Education: An Implementation Handbook. St. Lucie Press.

Davis, A Gary, Thomas A. Margaret. (2007). Effective School and Effective Teachers, Penyadur Jamaluddin Idris, Yogyakarta: Suluh Press.

Depdikbud, Panduan Manajemen Sekolah. (1998). Jakarta: Direktorat Jenderal Pendidikan Dasar dan Menengah Direktorat Pendidikan Menengah Umum.

Depdiknas. (2001). Kamus Besar Bahasa Indonesia, Jakarta: Balai Pustaka. (2002). Manajemen Peningkatan Mutu Berbasis Sekolah, Konsep Dasar, Jakarta: Ditjend Pendidikan Dasar dan Menengah.

E. Mulyasa. (2005). Menjadi Kepala Sekolah Profesional dalam Menyukseskan MBS dan KBK, Bandung: PT. Remaja Rosdakarya.

Fullan, Michael. (1982).The Meaning of Educational Change. New York \& London: Teachers Colege Press.

Hasnun, Anwar. (2010). Mengembangkan sekolah Efektif, Yogyakarta: Data Media.

Kambey, Daniel C. (2004). Landasan Teori Administrasi/Manajemen (Sebuah Intisari), Manado: Yayasan Tri Ganesha Nusantara.

Kompri. (2017). Standardisasi Kompetensi Kepala Sekolah, Pendekatan Teori untuk Praktik Profesional, Jakarta: Kencana.

Nurkholis. (2003). Manajemen Berbasis Sekolah, Teori, Model dan Aplikasi, Jakarta: PT. Gramedia Widiasarana Indonesia.

Qomar, Mujamil. (2007). Manajemen Pendidikan Islam, Jakarta: Erlangga.

Rohiat. (2009). Manajemen Sekolah, Teori Dasar dan Praktek, Bandung: PT. Refika Aditama.
Rizali, Ahmad, dkk. (2009). Dari Guru Konvensional Menuju Guru Profesional, Jakarta: PT. Grasindo.

Sagala, Syaiful. (2007). Manajemen Strategik dalam Peningkatan Mutu Pendidikan, Bandung: Alfabeta.

Sallis, Edward. (1993). Total quality management in education, London: Kogan Page Ltd.

Scheerens, J. \& Bosker, R. J. (1997). The Foundation of Education Effectiveness. New York: Pergamon Press

Strong, H . James, Richard, B Holly, Catano, Nancy, Qualities of Effective Principals, Alexandria, USA: Association for Supervision and Curriculum Development (ASCD)

Suryosubroto. (2004). Manajemen Pendidikan di Sekolah, Jakarta: PT. Rineka Cipta.

Umar, Yahya. (2011). Penilaian dan peningkatan Mutu Pendidikan di Indonesia, Jakarta: UIN Jakarta Press.

Widodo, Hendro. (2017). Budaya Unggul Kompetetif dan Komparatif di Sekolah, http://jurnaljogja.com/budayaunggul-kompetitif-dan-komparatifdi-sekolah/2017. 